2018-09

On the edge of exceptional

preservation: insights into the role of

redox state in Burgess Shale-type

taphonomic windows from the Mural

Formation, Alberta, Canada

\title{
Sperling, EA
}

http://hdl.handle.net/10026.1/11604

10.1042/ETLS20170163

Emerging Topics in Life Sciences

Portland Press Ltd.

All content in PEARL is protected by copyright law. Author manuscripts are made available in accordance with publisher policies. Please cite only the published version using the details provided on the item record or document. In the absence of an open licence (e.g. Creative Commons), permissions for further reuse of content should be sought from the publisher or author. 
On the edge of exceptional preservation: insights into the role of redox state in Burgess Shale-type taphonomic windows from the Mural Formation, Alberta, Canada

* Corresponding author:

Erik A. Sperling ${ }^{1 *}$, Uwe Balthasar ${ }^{2}$, Christian B. Skovsted $^{3}$

${ }^{1}$ Department of Geological Sciences, Stanford University, Stanford, CA, USA 94305

${ }^{2}$ School of Geography, Earth and Environmental Sciences, University of Plymouth, PL4 8AA, Plymouth, United Kingdom

${ }^{3}$ Department of Palaeobiology, Swedish Museum of Natural History, Box 50007, SE-104 05 Stockholm, Sweden

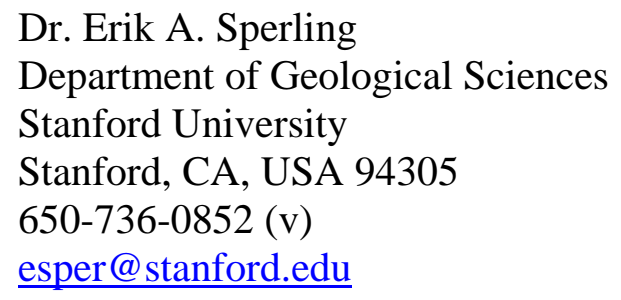




\section{Abstract}

Animals originated in the Neoproterozoic and 'exploded' into the fossil record in the Cambrian. The Cambrian also represents a high point in the animal fossil record for the preservation of soft tissues that are normally degraded. Specifically, fossils from Burgess Shaletype (BST) preservational windows give paleontologists an unparalleled view into early animal evolution. Why this time interval hosts such exceptional preservation, and why this preservational window declines in the early Paleozoic, have been long-standing questions. Anoxic conditions have been hypothesized to play a role in BST preservation, but recent geochemical investigations of these deposits have reached contradictory results with respect to the redox state of overlying bottom waters. Here, we report a multi-proxy geochemical study of the Lower Cambrian Mural Formation, Alberta, Canada. At the type section, the Mural Formation preserves rare recalcitrant organic tissues in shales that were deposited near storm wave-base (a Tier III deposit; the worst level of soft-tissue preservation). The geochemical signature of this section shows little to no evidence of anoxic conditions, in contrast to published multi-proxy studies of more celebrated Tier I and II deposits. These data help confirm that 'decay limited' BST biotas were deposited in more oxygenated conditions, and support a role for anoxic conditions in BST preservation. Finally, we discuss the role of iron reduction in BST preservation, including the formation of iron-rich clays and inducement of sealing seafloor carbonate cements. As oceans and sediment columns became more oxygenated and more sulfidic through the early Paleozoic, these geochemical changes may have helped close the BST taphonomic window. 
64 animal phylum in the fossil record within a geologically rapid span of $\sim 25$ million years. The

65 rapid increase in animal diversity and disparity is apparent in multiple records including the

66 normal shelly fossil record (e.g. brachiopods, trilobites; (1)), the trace fossil record (2-4),

67 phosphatized small shelly fossils (5-7) and small carbonaceous fossils (SCFs; $(8,9))$. The most

68 celebrated archive of this event, though, is from Burgess Shale-type (BST) deposits, where

69 primary organic tissues are preserved as thin carbonaceous films (see (10) for definitions).

70 Critically, these lagerstätten preserve the soft parts of animals, and while the communities do not

71 preserve a completely unbiased snapshot of early Cambrian life (for instance, size; (11)), they do

72 provide our best glimpse of early metazoan ecosystems (12-15). Most important, by preserving

73 most or all characters of an organism, fossils from BST biotas have been critical in

74 understanding the polarity and order of morphological character evolution within each individual 75 phylum (16).

76 The question of how organisms can escape the decay process, and why these BST

77 lagerstätten appears to be concentrated in the Cambrian period-even after accounting for factors

78 like rock outcrop area $(17,18)$ - has long intrigued geologists. It was recognized early on that low

79 oxygen levels (or complete anoxia) might play a prominent role in reducing decay. Actualistic

80 decay experiments, however, established that decay under anoxic conditions (at least in the

81 presence of normal marine sulfate levels) can still proceed rapidly $(19,20)$. For soft-bodied

82 deposits in general, then, anoxia mainly serves to 1) prevent scavenging, which would otherwise

83 destroy carcasses (21), and 2) help induce the precipitation of authigenic minerals, which are

84 involved in most exceptionally preserved deposits (22). In the most recent review of BST 
85 preservation (10), the window for abundant and exquisite BST fossil preservation is

86 hypothesized to occur in a 'goldilocks' zone near where the chemocline (the point in the water

87 column at which no oxygen remains) intersects the seafloor. At seafloor depths well below the

88 chemocline, the setting is 'supply limited' in that animals cannot live in anoxic conditions, and

89 carcasses simply cannot be supplied to these preservational settings through transport. Only

90 preservation of nektonic/planktonic organisms falling through the water column could potentially

91 occur. Conversely, at seafloor depths well above the chemocline, the setting is 'decay limited'

92 (preservation limited) in that aerobic degradation and bioturbating organisms quickly destroy

93 carcasses. Gaines (10) directly related the quality of preservation and species-level diversity of

94 BST biotas to the position of these deposits along the spectrum from 'supply limited' to 'decay

95 limited'. The most spectacular deposits, such as the Burgess Shale and Chengjiang (Tier 1), are

96 hypothesized to occur in the window where there is sufficient transport energy to carry soft-

97 bodied benthic organisms across the chemocline into anoxic waters. Tier II deposits such as

98 Kaili, Marjum and Spence lack sufficient transport energy or have source communities too far

99 up-slope above the chemocline, and so it is dominantly hydrodynamically light organisms (e.g.

100 algae) or dead carcasses that can be carried to the zone of exceptional preservation. Conversely,

101 the labile tissues of organisms living in-situ in these up-slope communities are only rarely

102 preserved due to the prevalence of more oxygenated conditions. Thus at different points along a

103 water-depth transect these Tier II deposits are both supply- and decay-limited. Tier III deposits

104 such as Latham or Indian Springs are hypothesized to have been deposited near storm wave-base

105 in relatively oxygenated conditions, and soft tissues are almost completely decomposed. Or in

106 another sense, only the most recalcitrant tissues are preserved (e.g., (23)). These Tier III sites are

107 consequently the most 'decay limited' in this classification scheme. 
109 mainly been developed on the basis of sedimentological and ichnological data (e.g., (24)). To test

110 this framework, in recent years geochemists have applied several tools to the question, most

111 notably iron speciation analysis and the study of redox-sensitive trace metal concentrations. Both

112 of these proxies rely on identifying enrichments of specific phases or elements (that are known to

113 be incorporated into sediments under reducing conditions) relative to average crustal values or

114 empirically determined shale baselines. Iron speciation tracks the ratio of total iron (FeT) to

115 highly reactive iron phases (FeHR; iron in pyrite plus those iron phases reactive to sulfide on

116 early diagenetic timescales, including iron oxides, iron carbonates and magnetite). In the modern

117 ocean, samples deposited beneath an oxygenated water column have FeHR/FeT $<0.38(25,26)$.

118 Samples deposited beneath an anoxic water column generally have ratios $>0.38$, although rapid

119 deposition, for instance in turbidites, can mute enrichments (the lowest modern anoxic samples

120 have ratios as low as $0.20 ;(25,27))$. Critically, this proxy can also distinguish different types of

121 anoxic water columns: between anoxic and ferruginous water columns (those with free ferrous

122 iron, or more specifically not enough sulfide production to titrate available reactive iron) and

123 anoxic and euxinic water columns (with free sulfide). This is accomplished by examining the

124 proportion of reactive iron that has been pyritized (FeP; represents iron in pyrite). Generally,

125 anoxic samples with FeP/FeHR > 0.7-0.8 are interpreted as euxinic, with ratios below this

126 interpreted as ferruginous (26). As discussed below, whether a water column was ferruginous

127 versus euxinic has important implications for interpreting trace metal patterns, and, perhaps, BST 128 preservation itself.

129 Analysis of redox-sensitive trace metal concentrations relies on the observation that these 130 elements (such as molybdenum, uranium, vanadium or chromium) are generally soluble in 
131 oxygenated water columns, and become insoluble and form complexes with organic matter,

132 sulfides or other mineral phases upon reduction in suboxic (only trace amounts of oxygen

133 present; $0.1 \mathrm{~mL} / \mathrm{L}$ ) or anoxic (zero oxygen) water columns (28). Such authigenic metal

134 enrichments are identifiable by comparing concentrations in a given shale sample against

135 baselines meant to represent the background detrital input, such as world average shale (29) or

136 average upper continental crust (30). Concentrations above these baselines would point towards

137 authigenic enrichment, and by inference, a reducing water column. Like with iron speciation,

138 rapid deposition will result in less time for authigenic enrichments to accumulate.

139 The sequestration pathways for each element are unique, with different reducing

140 conditions and the presence/absence of sulfide having large effects on the level of enrichment.

141 For instance, sulfide levels $>11 \mu \mathrm{M}$ are required for the quantitative switch from molybdate

142 anion to tetrathiomolybdate, which increases particle reactivity and hence the removal of Mo

143 from the water column into the sediment (31,32). Vanadium does not require sulfidic conditions

144 for initial reduction, but also undergoes a second reduction step in the presence of significant

145 sulfide levels (33), and the presence of large sedimentary V enrichments may require sulfide.

146 Historically, most of the research on authigenic metal enrichment has focused on modern

147 systems or Mesozoic Ocean Anoxic Events, both of which are characterized by water columns

148 and sediments that were generally sulfidic when anoxic. However, ferruginous conditions are

149 increasingly being identified throughout pre-Mesozoic oceans (26,34-36), and recent debate has

150 focused on expected metal enrichments under such conditions (27,37-40). Although this debate

151 remains open with respect to the exact magnitude of enrichment expected, studies have agreed

152 that redox-sensitive metal enrichments will be relatively muted in ancient ferruginous settings.

153 Further complicating the picture, two elements whose enrichment does not depend on the strict 
154 presence of sulfide — vanadium and chromium - are the redox-sensitive metals most influenced

155 by variations in the detrital fraction, making the detection of muted enrichments difficult $(28,41)$.

\section{Redox studies of BST deposits}

Analyses using iron speciation and some studies of redox-sensitive metal concentrations

159 have provided contrasting interpretations of redox state during deposition of Burgess Shale-type 160 deposits. Consistent with a role for anoxia in the preservational model, iron speciation analyses

161 of the Series 3 Wheeler Shale, Utah, have indicated a mixture of ferruginous and oxic conditions

$162((35,42)$; although note that no data to date has been presented in stratigraphic or paleontological

163 context). An iron speciation and trace metal abundance investigation of the Series 2 Chengjiang

164 lagerstätte, South China, revealed euxinic conditions stratigraphically beneath the exceptionally

165 preserved deposits, followed by the development of more 'equivocal' conditions in the zone of

166 exceptional preservation (43). Specifically, FeP/FeHR ratios were $<0.7$, and FeHR/FeT ratios

167 were between 0.2 and 0.38 , which in combination with low Mo concentration and in the context

168 of the turbiditic setting, could indicate either an oxic or ferruginous water column $(43,44)$.

169 Nitrogen isotopes were also investigated in these Chengjiang cores, and showed a more readily

170 interpretable signal. Hammarlund et al. (43) suggested, based on positive nitrogen isotope values,

171 that the water column was strongly denitrifying (similar to the cores of modern Oxygen

172 Minimum Zones; OMZs) above the zone of exceptional preservation. Overall, these data point

173 towards 'suboxic' to anoxic (but non-sulfidic) conditions during deposition of the Chengjiang

174 BST deposits. Echoing these results, a detailed multi-proxy study of the Series 2 Sirius Passet

175 deposit in North Greenland reported transiently anoxic (ferruginous) conditions during the

176 interval of highest soft-bodied fossil abundance and diversity (45). 
In contrast, trace metal data from these and other BST deposits have been interpreted as

178 indicative of oxygenated conditions at the seafloor. Near-crustal levels of redox-sensitive metals

179 (e.g. Mo, U, V, Cr) have been found in the Burgess Shale itself (46), Chengjiang (42,43; though

180 higher abundances were found in the lower Maotianshan Shale), Sirius Passet (47), Emu Bay

181 lagerstätte in South Australia (48), the Rockslide Formation in northwestern Canada (49), the

182 Wheeler and Spence shales in Utah (44) and the Indian Springs lagerstätte, Nevada (50). These

183 relatively low enrichments have generally been interpreted as representing a purely detrital trace

184 metal source and an oxygenated water column. Consequently, it has also been inferred that

185 anoxia did not play a role (or was not required) for BST preservation. In some cases, the

186 robustness of these trace metal signals has been questioned because some deposits (such as the

187 Burgess Shale and Sirius Passet) have experienced considerable metamorphism (24). However,

188 given the consistent and widespread pattern in deposits with lower metamorphic grade, this is

189 probably a primary depositional signature. But while likely primary, the common interpretative

190 paradigm that low redox-sensitive trace metal contents indicate oxygenated conditions (e.g.

191 Jones and Manning ref. (51)) was developed prior to our current understanding that anoxic but

192 non-sulfidic (ferruginous) water columns - with low trace metal enrichments compared to

193 euxinic systems - are common in the geological record. Given this new framework, these

194 published trace metal data provide no evidence for euxinic conditions, but they are also

195 consistent with the muted trace metal enrichments predicted for shale deposited under a

196 ferruginous water column. Thus the role of redox state in BST preservation remains

197 controversial.

198

199 The Mural Formation: a test case 
The Lower Cambrian (Series 2) Mural Formation, exposed in the southern Canadian

201 Cordillera (Fig. 1), offers an opportunity to refine our understanding of the role of redox state in

202 BST preservation. In terms of preservation, the Mural Formation contains elements of BST soft-

203 bodied preservation in one known locality near Mumm Peak (Fig. 1; Fig. 2D, E), but compared

204 to Tier I and II biotas such as the Burgess Shale, Sirius Passet, Emu Bay, or Chengjiang, it is by

205 no means 'exceptional' in terms of abundance or preservational fidelity. In essence, it preserves

206 recalcitrant cuticles rather than fine morphologies. Also in contrast to most BST deposits that

207 were deposited well beneath storm wave-base (10), the Mural Formation shows evidence of

208 storm activity in stratigraphic proximity to the beds with exceptional preservation. The Mural

209 Formation therefore represents an end-member of BST preservation: perhaps deposited in

210 slightly shallower water, and with soft-part preservation not seen in standard shelly faunas, but

211 not as exceptional as the deservedly more famous BST deposits. In the classification of Gaines

212 (10) this is a 'Tier 3' BST deposit (the worst level of fossil preservation). The goal of this study

213 is to conduct a multi-proxy sedimentary geochemical study of the BST-preservation interval in

214 the Mural Formation - the first such study of a Tier 3 deposit — and compare the results against

215 data obtained from other BST deposits worldwide. Overall this work provides data from a

216 preservational end-member on the role of oxygen in BST taphonomy and an important

217 consistency test of existing hypotheses: if anoxia plays a central role in exceptional BST

218 preservation, we would predict a more oxygenated signal in the Mural Formation than the

219 investigated Tier I and II deposits.

220

221 Geologic Background 
The Mural Formation was deposited during the early Cambrian Sauk transgression on the

223 western Laurentian margin (52,53), and sits above the 300-1700 meter thick shallow-marine

224 siliciclastics of the McNaughton Formation (54,55). The McNaughton is generally thought to

225 represent the rift-to-post-rift transition on the Laurentian margin $(56,57)$ although continued syn-

226 sedimentary faulting continued through the mid-Cambrian to the north. The Mural Formation is

227 part of a broadly contiguous stratigraphic package spanning the Nevadella-Bonnia/Olenellus

228 trilobite zones (Series 2; Waucoban) that stretches from Mexico to Yukon, Canada (52). This

229 package consists of an upper and lower carbonate composed of ooid grainstone shoals and

230 archaeocyath bioherms, separated by a medial shale/siltstone (Fig. 3).

231 The Mural Formation has been the subject of paleontological investigation for more than

232 a century (primarily at its type section near Mumm Peak, Jasper National Park, the focus of study

233 here), and workers have described an abundant shelly fauna including trilobites and obollelid and

234 linguliform brachiopods (58-63). Two known levels have also yielded soft-part preservation

235 (Fig. 3), the 'Lingulosacculus quarry' that preserves soft-shelled brachiopods (64) (Fig. 2E), and

236 the 'waterfall quarry' level which contains as-yet undescribed vetulicolians, palaeoscolecid

237 worms, and anomalocarid appendages (Fig. 2D). These soft-bodied preservation levels are

238 located in grey, laminated shales between packages of shale containing beds and lenses of

239 detrital carbonates, sometimes comprised of fossil hash. Whether these storm beds represent a

240 shallowing into storm wave base during sea-level change (i.e. parasequences) or occasional

241 storm beds at a constant depth could not be determined, but in either case this represents a

242 proximity to wave base not seen in Type I and II BST deposits (10). The Mural Formation does

243 not display bioturbation through the medial shale. 
27 shale samples were collected from the Mural Formation, all from the medial shale at

247 the type section, and crushed in a tungsten carbide shatterbox. Total organic carbon (TOC)

248 weight percent was analyzed on decalcified residue on a Carlo-Erba NA 1500 Elemental

249 Analyzer. Weight percent iron in pyrite $(\mathrm{FeP})$ was quantified using the chromium reducible

250 sulfur method of Canfield et al. (65), and iron present in iron oxides, iron carbonates and

251 magnetite was quantified using the sequential extraction method of Poulton and Canfield (66).

252 Precision estimates for these methods can be found in the supplementary materials of $(35,40)$.

253 Major, minor and trace element concentrations were analyzed by Bureau Veritas, Ltd., using

254 ICP-MS/ICP-OES following multi-acid digestion. Aliquots of the USGS shale standards SBC-1

255 and SGR-1 were sent blind along with samples, and results were consistent with published 256 values.

\section{Results and discussion}

259 All geochemical results are plotted on Figure 3 and reported in the Supplementary

260 Information. Total organic carbon (TOC) weight percents in the Mural Formation are relatively

261 low, at $0.14 \pm 0.03$ (one standard deviation). This probably rules out very high original

262 sedimentary TOC values (as this signature can be retained even in the face of metamorphism,

263 e.g., (67), but as these are outcrop samples from a region that has experienced prehnite-

264 pumpellyite grade (CAI of 3-5) metamorphism (68), the original TOC-richness is unknown and

265 certainly higher. Redox-sensitive trace metal contents are uniformly low and around

266 crustal/average shale values. Specifically, Mo contents are all $<1 \mathrm{ppm}, \mathrm{U}$ contents are $2.6 \pm 0.4$

267 ppm, and V contents are $88 \pm 8 \mathrm{ppm}$. As aluminum, a conservative tracer of detrital input, is also 
268 near or even slightly elevated compared to average shale values $(9.4 \pm 0.5$ weight percent $)$, the

269 low redox-sensitive trace metal contents in the Mural cannot be explained by dilution by

270 carbonates or other non-clastic material. Trace metal data are plotted in Figure 3 as Enrichment

271 Factors (EF), which is a method of accounting for the expected detrital metal input based on

272 observed levels of a biogeochemically conservative element such as aluminum (discussed in

273 (28)). Values $>>1$ would indicate authigenic enrichment (due to reducing conditions). Values

274 around 1 generally indicate the operation of purely detrital processes and oxic conditions,

275 however since there is so much possible variability in detrital input (41), and substantial

276 authigenic metal enrichments might also not develop during rapid sedimentation, recognizing

277 whether there have actually been slight enrichments or depletions is difficult to tell. The Mural

278 Formation data unfortunately falls in this zone. Thus, like many other BST deposits investigated

279 to date, the Mural Formation trace metal data rule out euxinic conditions but are consistent with

280 either an oxic (no enrichment) or ferruginous (possibly muted enrichment) water column during 281 deposition.

282 The iron geochemistry of the Mural Formation, though, differs from that of investigated

283 BST deposits. FeHR/FeT values are low $(0.17 \pm 0.04)$, with all of the values being well below

284 the 0.38 ratio usually taken as indicative of an anoxic water column. The most straightforward

285 explanation of these data is oxic deposition. However, it has been recognized that 1)

286 fingerprinting anoxia is generally more straightforward than oxic conditions $(37,69)$ and 2) there

287 are a number of factors that can result in low FeHR enrichment (rapid deposition and source area

288 effects) or drive FeHR/FeT values lower (metamorphism). Regarding rapid deposition, the

289 medial shale does not have consistent sedimentological indicators of such processes, although it

290 should be noted that obvious sedimentary structures are difficult to see in outcrop. There is 
291 evidence for event-driven sedimentation in a relatively thick sandstone marker bed right above

292 the exceptionally preserved interval. Considering that almost all BST deposits involve event-

293 based sedimentation (10), more detailed sedimentological and petrographic study of the Mural

294 Formation may reveal additional evidence of these processes. Nonetheless, the observed

$295 \mathrm{FeHR} / \mathrm{FeT}$ values are still generally lower than the lowest 0.2 ratio recognized in the modern

296 ocean for anoxic turbidites (27), suggesting a most parsimonious interpretation of oxic

297 conditions even with respect to this caveat. Second, in some cases there may not be an

298 appropriate source of detrital iron available to be shuttled into the anoxic basin, and it is this

299 shuttle that ultimately generates the iron enrichments this proxy targets (discussed in (69)).

300 However, such settings are relatively rare, and stratigraphically underlying anoxic

301 Neoproterozoic strata exhibit obvious iron enrichments (36). Perhaps the most important

302 consideration for the Mural is that highly reactive iron can be converted to poorly reactive iron

303 during metamorphism, removing the evidence for anoxic sedimentation $((26,70)$. Fortunately,

304 total iron (relative to aluminum) is also generally enriched by the iron shuttle under anoxic water

305 columns $(71,72)$, and this ratio is not as strongly affected by metamorphism. With the exception

306 of one sample (interestingly, at the level of the Lingulosacculus quarry; Fig. 3), the Fe/Al values

$307(0.48 \pm 0.11)$ are exactly within the range expected of oxic sediments (72). In summary, although

308 we cannot unambiguously rule out anoxic conditions, we can state 1) the only possible anoxic

309 signal —in just one of multiple proxies — occurs at one of the soft-bodied preservation levels, and

310 2) all other available evidence points towards the presence of at least some oxygen in the water

311 column (or more precisely, provides no evidence for anoxia).

312 The Mural Formation thus preserves elements of BST biotas and has no evidence for

313 anoxia. Although seemingly paradoxical, we argue this provides strong evidence for the role of 
314 anoxic or periodically anoxic conditions in BST preservation. Put simply, the preservation in the

315 Mural Formation is nowhere near that in the celebrated BST deposits. There is no exquisite,

316 high-fidelity preservation of nervous systems, eyes, gut details, gills, etc. as in other deposits

317 (73-76). The fossils preserved in the Mural Formation at Mumm Peak are the recalcitrant end-

318 members of BST preservation: soft-shelled brachiopods (64), anomalocarid appendages, etc.

319 Exceptionally preserved fossils in the Mural Formation are also rare and low-diversity; despite

320 extensive quarrying during our fieldwork, we did not uncover new taxa that had not been found

321 by previous field parties. Core

322 When comparing between BST deposits, it is worth noting that the overall differences in

323 redox state may have been slight. For instance, the Mural is not extensively burrowed,

324 suggesting the water column was not fully oxygenated. And some of the other more spectacular

325 BST deposits may have been deposited in conditions that rapidly alternated between dysoxic and

326 anoxic/ferruginous conditions, with the chemocline established perhaps only slight above the

327 sediment-water interface (24). However, even considering the known difficulty of tracking low-

328 oxygen conditions with available geochemical proxies (77), it is apparent that exceptional BST

329 deposits (Tier 1 and 2) have a much greater prevalence of anoxic iron speciation signatures

330 and/or total iron enrichments, minor but observable trace metal enrichments, and positive

331 nitrogen isotope values $(35,42,43,45)$ than the Mural Formation. In other words, there is now

332 geochemical evidence suggesting both the Mural Formation and the transition between the upper

333 Maotianshan Shale and Yuanshan Member 3 in the Chengjiang deposit (43) were more

334 oxygenated and 'decay limited' than Tier I and II deposits. This confirms previous analyses

335 based on detailed sedimentological and ichnological studies that preservation in BST deposits

336 was facilitated by anoxic conditions (24). 


\section{Towards a refined geochemical model}

Moving forward, it is clear that anoxia was likely involved in preserving BST fossils, but

340 it is also clear from both sedimentological/ichnological approaches $(24,78,79)$ and multi-proxy

341 geochemical studies $(43,45)$ that these deposits were near the edge of the chemocline, with often-

342 times rapid fluctuations into low-oxygen (suboxic/dysoxic) conditions. Tracking low oxygen

343 levels is difficult with our current geochemical toolkit (77), and further, the

344 ecological/oceanographic timescales that matter for organismal habitat viability and fossil

345 preservation often differ from the integrated longer-term geochemical signals studied in hand

346 samples collected by geochemists (27). Indeed, no published multi-proxy BST dataset is

347 completely unambiguous; such ambiguity may actually be a hallmark of very low-oxygen or

348 fluctuating oxic/anoxic systems. In light of this, further gains in understanding of the role of

349 redox conditions will require new approaches. These may include increased efforts to obtain

350 unoxidized drill cores (packsack or 'winky' drills may offer an alternative to a full drill rig; e.g.,

351 (80)), and moving from standard bulk-rock geochemistry (such as in this study) to increased

352 micron- and phase-specific interrogation of the geochemical signal, especially in more

353 metamorphosed deposits. Shale-based proxies that can unambiguously resolve oxygenated

354 conditions would also be a major step forward.

355 Most important, geochemical studies should strive towards a multi-proxy approach

356 incorporating as many sources of data as possible, but especially pairing redox-sensitive trace

357 metal analysis with iron speciation. The recognition that water columns were commonly

358 ferruginous (non-euxinic) during this time interval will often make interpretation of trace metal

359 data more difficult. Low Mo abundances are helpful in ruling out fully euxinic water columns 
$360(81,82)$, but in the absence of iron speciation data (the best available method for fingerprinting

361 anoxic but non-euxinic conditions), low concentrations of elements like $\mathrm{U}, \mathrm{V}$, and $\mathrm{Cr}$ are

362 inconclusive as they could indicate either oxic or ferruginous conditions. Like the Mural

363 Formation, some other 'Tier 3' lagerstätte such as Indian Springs might have been deposited

364 under an oxic water column (50), but this cannot be determined from trace metal data alone. A

365 further issue lies in choosing baseline values. Many studies compare redox-sensitive data to the

366 interpretive scheme of Jones and Manning (51). This study was groundbreaking in its time

367 (especially the cross-validation approach), but current consensus is that the scheme is optimistic

368 in its true ability to detect such subtle redox shifts. Redox-sensitive trace metal behavior in

369 sediments and the water column is complicated, and many of the Jones and Manning proxies

370 (e.g. $\mathrm{V} /(\mathrm{V}+\mathrm{Ni}), \mathrm{Ni} / \mathrm{Co}$ or $\mathrm{V} / \mathrm{Cr}$ ) take two elements, each with incompletely understood redox

371 properties and perhaps different detrital influences, and combine them together. The sum here is

372 likely less than the parts. In light of this, we propose abandoning the Jones and Manning

373 framework. Nuanced understanding of redox patterns with trace metals remains possible, but this

374 should come through careful comparative study of metal data as single-element enrichment

375 factors or metal/aluminum ratios (while paying heed to possible variation in detrital inputs (41))

376 and with respect to more modern chemical oceanographic studies.

377 How exactly anoxic (or fluctuating anoxic-to-dysoxic) conditions directly impacted BST

378 preservation remains unclear. On the one hand, anoxia is a necessary but insufficient prerequisite

379 for BST preservation by eliminating scavenging $(10,19,21)$. Early calcium carbonate

380 cementation and low oceanic sulfate levels may have been equally important in sealing beds

381 from oxidant delivery and reducing microbial decay (83). Beyond simply considering 'anoxia,' it

382 may actually be the specific flavors of anoxia in the sediment and water column that are 
383 important in controlling preservation. Specifically, 'suboxic' microbial processes such as iron

384 and manganese reduction dramatically increase alkalinity relative to dissolved inorganic carbon

385 (DIC) and thus raise the calcium carbonate saturation state of porewaters. In contrast, sulfate

386 reduction increases alkalinity equal to DIC, and moves saturation state along lines of roughly

387 equal values $(\Omega)(84)$. Enhanced iron reduction in Cambrian sediments could therefore have

388 helped induce precipitation of the observed BST seafloor cements critical for 'sealing' carcasses

389 in the sediment. It is worth noting here that many, but not all, of the BST cement layers carry a

390 dominant seawater (rather than microbial) carbon isotope signature (83). However a seawater

391 carbon signature can also be found in other carbonate precipitates believed to be triggered by

392 'suboxic' microbial metabolisms (84). Essentially, a dominantly seawater carbon isotope

393 signature does not negate a role for iron reduction, but rather suggests that relatively little

394 microbial respiratory work was required to tip the scales and induce precipitation (84).

395 The fact that there was abundant iron reduction relative to sulfate reduction during early

396 diagenesis in BST deposits has recently been demonstrated by clay mineralogy studies. A recent

397 investigation of 19 Cambrian sedimentary successions on four continents found that BST

398 deposits were highly correlated with the presence of iron-rich clay minerals (berthierine and

399 chamosite) compared to deposits only containing shelly fossils (85). These clays form during

400 early diagenesis by the transformation of detrital clays in the presence of elevated pore-water

$401 \mathrm{Fe}^{2+}$. The exact role of these clays in preservation is unclear, specifically whether they are simply

402 a symptom of some other factor important in BST preservational pathways, or a cause $(86,87)$.

403 Certainly, clays appear to function as anti-microbial agents in decay experiments (88), but the

404 action of iron-rich clays is not significantly different from precursors like kaolinite, and the

405 timescale for the formation of berthierine and chamosite is longer than the timescale required for 
406 labile tissue preservation. In any case, considering that pore-water $\mathrm{Fe}^{2+}$ will not accumulate in 407 the presence of sulfide (89), it is significant that anoxic Cambrian water columns and sediments 408 appear to have had relatively low sulfide-generating potential (35). Thus, a transition in the 409 uppermost sediment column away from extensive iron reduction, and towards sulfate reduction 410 (such as we see in modern OMZs) over the early Phanerozoic may have played multiple

411 geochemical roles in the disappearance of BST preservation. In this view, a transition towards 412 more oxygenated oceans with time may have been important (18), but this alone would be too 413 simplistic; the relative rates of iron versus sulfate reduction matter too. In other words, as oxygen 414 and sulfate levels rose through the Paleozoic $(90,91)$, changes in sediments and water columns 415 towards either more oxic or more sulfidic conditions may have inhibited BST preservational 416 pathways. Most likely, the Burgess Shale-type taphonomic window was propped open by a 417 'perfect storm' of geochemical parameters in the Cambrian ocean $(18,83,86,92)$.

\section{Summary Points}

421 - Poor preservation in Burgess Shale-type deposits is linked to relatively more oxygenated 422 conditions, suggesting anoxia likely played a role in the most exceptionally preserved 423 deposits.

424 - The relative dominance of iron reduction compared to sulfate reduction in Cambrian 425 sediments and water columns may have played a key role in factors required for Burgess 426 Shale-type preservation. 
We thank Una Farrell, Austin Miller, David Mucciarone and Douglas Turner for lab assistance, Jen Wasylyk at Parks Canada for permitting and logistical help, Jakob Vinther for field assistance, Richard Stockey and Ross Anderson helpful discussion, and Bob Gaines and an anonymous reviewer for formal comments. We thank Yellowhead helicopters for safe flying. We Northern Europe GEFNE113-14.

Figure 1- A, B: Geographic position of the Mural Formation section studied here. C: Geological map of the study region, after GSC Map 1499A (93) and modified from (62).

Figure 2- Sedimentology and paleontology of the medial shale/siltstone of the Mural Formation near Mumm Peak. A: Unlike exquisitely preserved Tier I and II BST deposits, the medial shale contains beds and lenses of detrital carbonate with indications of wave or current activity, such as cross beds (arrow). Photo from 107.4 meters; mechanical pencil for scale. B) Shale beds immediately adjacent to beds with current structures have a shelly fauna, with evidence of transport, such as this cluster of trilobite cephalons. Photo from local float at 117 meters, mechanical pencil for scale. C) The lower half of the medial shale also contains laminated grey shale intervals, such as this photo spanning 114-115 meters, at the 'waterfall quarry' level. 30 $\mathrm{cm}$ geological hammer for scale. These intervals host rare soft-bodied preservation. D) In-situ fragment of anomalocarid claw (arrow), from 114 meters (within 'waterfall quarry'); diameter of Canadian quarter is $24 \mathrm{~mm}$. E) Lingulosacculus nuda (64) with preserved gut trace (arrow), from 'Lingulosacculus quarry' at 118.2-118.6 meters. $5 \mathrm{~mm}$ scale bar on photo.

Figure 3- Lithostratigraphy and sedimentary geochemistry of the Mural Formation at Mumm Peak. Total measured thickness of the Formation is very similar to that of (59) but the heights of internal units differ slightly. Nevadella-Bonnia/Olenellus boundary is resolved to a $3.85 \mathrm{~m}$ interval between $117.3 \mathrm{~m}$ and $121.15 \mathrm{~m}$. Inset shows expanded stratigraphy of medial shale/siltstone. Geochemical data from left-to-right: 1) The iron speciation proxy (FeHR/FeT). Values above the vertical 0.38 line likely represent deposition under an anoxic water column, based on calibrations from the modern ocean (25). Oxic samples in the modern fall below this line, but anoxic samples can too, for instance during turbiditic sedimentation. The dashed 0.2 line represents the lowest modern value for an anoxic turbiditic sediment. FeP/FeHR values not graphed as all samples show an oxic signature; the average is $0.29 \pm 0.15$ (Supplemental Information) (27). 2) Fe/Al ratio, with shaded blue bar representing the range of values seen in ancient oxic shale (72). Values above this bar would indicate iron enrichment due to an anoxic water column. 3) Molybdenum Enrichment Factor (EF). 4) Uranium EF. 5) Vanadium EF. For these samples, an Enrichment Factor of 1 represents an aluminum-normalized value equal to upper continental crust (30). Values above 1 indicate enrichment, although recognition of muted enrichments can be difficult due to variations in detrital input (41). Enrichment would be expected under an anoxic water column (28), yet all of these samples are unenriched. McNton. = McNaughton Formation; W. = 'waterfall quarry' level from 112.8-114.9m; L. = 'Lingulosacculus quarry' from 118.2-118.6m. 
1. Erwin DH, Laflamme M, Tweedt SM, Sperling EA, Pisani D, Peterson KJ. The Cambrian conundrum: Early divergence and later ecological success in the early history of animals. Science. 2011;334(6059):1091-7.

2. Droser ML, Gehling JG, Jensen S. When the worm turned: Concordance of Early Cambrian ichnofabric and trace-fossil record in siliclastic rocks of South Australia. Geology. 1999;27:625-8.

3. Droser ML, Bottjer DJ. Trends in depth and extent of bioturbation in Cambrian carbonate marine environments, western United States. Geology. 1988;16:233-6.

4. Buatois LA, Mángano MG, Olea RA, Wilson MA. Decoupled evolution of soft and hard substrate communities during the Cambrian Explosion and Great Ordovician Biodiversification Event. Proc Natl Acad Sci. 2016 Jun 21;113(25):6945-8.

5. Porter SM. Closing the phosphatization window: Testing for the influence of taphonomic megabias on the pattern of small shelly fossil decline. Palaios. 2004;19:178-83.

6. Smith EF, Macdonald FA, Petach TA, Bold U, Schrag DP. Integrated stratigraphic, geochemical, and paleontological late Ediacaran to early Cambrian records from southwestern Mongolia. GSA Bull. 2016 Mar 1;128(3-4):442-68.

7. Maloof AC, Porter SM, Moore JL, Dudas FO, Bowring SA, Higgins JA, et al. The earliest Cambrian record of animals and ocean geochemical change. Geol Soc Am Bull. 2010;122:1731-74.

8. Butterfield N, Harvey T. Small carbonaceous fossils (SCFs): A new measure of early Paleozoic paleobiology. Geology. 2012;40(1):71-4.

9. Harvey THP, Vélez MI, Butterfield NJ. Exceptionally preserved crustaceans from western Canada reveal a cryptic Cambrian radiation. Proc Natl Acad Sci. 2012;109(5):1589-94.

10. Gaines RR. Burgess Shale-type Preservation and its Distribution in Space and Time. Paleontol Soc Pap. 2014 Oct;20:123-46.

11. Sperling EA. Tackling the 99\%: can we begin to understand the paleoecology of the small and soft-bodied animal majority? In: Bush AM, Pruss SB, Payne JL, editors. Ecosystem paleobiology and geobiology. 2013. p. 77-86.

12. Conway Morris SC. The community structure of the Middle Cambrian Phyllopod Bed (Burgess Shale). Palaeontology. 1986;29:427-67.

13. Briggs DEG. Extraordinary fossils reveal the nature of Cambrian life: a commentary on Whittington (1975) 'The enigmatic animal Opabinia regalis, Middle Cambrian, Burgess Shale, British Columbia.’ Phil Trans R Soc B. 2015 Apr 19;370(1666):20140313.

14. Briggs DEG. Extraordinary Fossils. Am Sci. 1991;79(2):130-41. 
15. Caron J-B, Jackson DA. Paleoecology of the Greater Phyllopod Bed community, Burgess Shale. Palaeogeogr Palaeoclimatol Palaeoecol. 2008 Feb 18;258(3):222-56.

512 16. Briggs DEG, Fortey RA. Wonderful strife: systematics, stem groups, and the phylogenetic signal of the Cambrian radiation. Paleobiology. 2005;31 Supplement:94-112.

17. Allison PA, Briggs DEG. Exceptional fossil record: Distribution of soft-tissue preservation

21. Skinner ES. Taphonomy and depositional circumstances of exceptionally preserved fossils from the Kinzers Formation (Cambrian), southeastern Pennsylvania. Palaeogeogr Palaeoclimatol Palaeoecol. 2005;220(1-2):167-92.

22. Briggs DEG. The role of decay and mineralization in the preservation of soft-bodied fossils. Annu Rev Earth Planet Sci. 2003;31:275-301.

23. Naimark E, Kalinina M, Boeva N. PERSISTENCE OF EXTERNAL ANATOMY OF SMALL CRUSTACEANS IN A LONG TERM TAPHONOMIC EXPERIMENT. PALAIOS. 2018 Apr 10;33(4):154-63.

24. Gaines RR, Droser ML. The paleoredox setting of Burgess Shale-type deposits. Palaeogeogr Palaeoclimatol Palaeoecol. 2010 Nov 20;297(3):649-61.

25. Raiswell R, Canfield DE. Sources of iron for pyrite formation in marine sediments. Am J Sci. 1998;298:219-45.

26. Poulton SW, Canfield DE. Ferruginous conditions: A dominant feature of the ocean through Earth's history. Elements. 2011;7(2):107-12.

27. Sperling EA, Carbone C, Strauss JV, Johnston DT, Narbonne GM, Macdonald FA. Oxygen, facies, and secular controls on the appearance of Cryogenian and Ediacaran body and trace fossils in the Mackenzie Mountains of northwestern Canada. Geol Soc Am Bull. 2016;128:558-75.

28. Tribovillard N, Algeo TJ, Lyons T, Riboulleau A. Trace metals as paleoredox and paleoproductivity proxies: An update. Chem Geol. 2006;232(1):12-32. 
29. Turekian KK, Wedepohl KH. Distribution of the elements in some major units of the earth's crust. Geol Soc Am Bull. 1961;72(2):175-92.

30. McLennan SM. Relationships between the trace element composition of sedimentary rocks and upper continental crust. Geochem Geophys Geosystems. 2001 Apr 1;2(4):1021.

31. Helz GR, Miller CV, Charnock JM, Mosselmans JFW, Pattrick RAD, Garner CD, et al. Mechanism of molybdenum removal from the sea and its concentration in black shales: EXAFS evidence. Geochim Cosmochim Acta. 1996 Oct 1;60(19):3631-42.

32. Erickson BE, Helz GR. Molybdenum(VI) speciation in sulfidic waters:. Stability and lability of thiomolybdates. Geochim Cosmochim Acta. 2000 Apr 1;64:1149-58.

33. Wanty RB, Goldhaber MB. Thermodynamics and kinetics of reactions involving vanadium in natural systems: Accumulation of vanadium in sedimentary rocks. Geochim Cosmochim Acta. 1992 Apr 1;56(4):1471-83.

34. Guilbaud R, Poulton SW, Butterfield NJ, Zhu M, Shields-Zhou GA. A global transition to ferruginous conditions in the early Neoproterozoic oceans. Nat Geosci. 2015;8:466-70.

35. Sperling EA, Wolock CJ, Morgan AS, Gill BC, Kunzmann M, Halverson GP, et al. Statistical analysis of iron geochemical data suggests limited late Proterozoic oxygenation. Nature. 2015 Jul 22;523(7561):451-4.

36. Canfield DE, Poulton SW, Knoll AH, Narbonne GM, Ross G, Goldberg T, et al. Ferruginous conditions dominated later Neoproterozoic deep-water chemistry. Science. 2008;321:94952 .

37. Sperling EA, Rooney AD, Hays L, Sergeev VN, Vorob'eva NG, Sergeeva ND, et al. Redox heterogeneity of subsurface waters in the Mesoproterozoic ocean. Geobiology. 2014;12:373386.

38. Li C, Planavsky NJ, Love GD, Reinhard CT, Hardisty D, Feng L, et al. Marine redox conditions in the middle Proterozoic ocean and isotopic constraints on authigenic carbonate formation: Insights from the Chuanlinggou Formation, Yanshan Basin, North China. Geochim Cosmochim Acta. 2015 Feb 1;150:90-105.

39. Marz C, Poulton SW, Beckmann B, Kuster K, Wagner T, Kasten S. Redox sensitivity of P cycling during marine black shale formation: Dynamics of sulfidic and anoxic, non-sulfidic bottom waters. Geochim Cosmochim Acta. 2008;72:3703-17.

40. Miller AJ, Strauss JV, Halverson GP, MacDonald FA, Johnston DT, Sperling EA. Tracking the onset of Phanerozoic-style redox-sensitive trace metal enrichments: New results from basal Ediacaran post-glacial strata in NW Canada. Chem Geol. 2017 Mar 1;457:24-37.

41. Cole DB, Zhang S, Planavsky NJ. A new estimate of detrital redox-sensitive metal concentrations and variability in fluxes to marine sediments. Geochim Cosmochim Acta. 2017 Oct 15;215:337-53. 
42. Raiswell R, Canfield DE. The iron biogeochemical cycle past and present. Geochem Perspect. 2012;1(1):1-322.

43. Hammarlund EU, Gaines RR, Prokopenko MG, Qi C, Hou X-G, Canfield DE. Early Cambrian oxygen minimum zone-like conditions at Chengjiang. Earth Planet Sci Lett. 2017 Oct 1;475:160-8.

44. Kloss TJ, Dornbos SQ, Chen J-Y, McHenry LJ, Marenco PJ. High-resolution geochemical evidence for oxic bottom waters in three Cambrian Burgess Shale-type deposits. Palaeogeogr Palaeoclimatol Palaeoecol. 2015 Dec 15;440:90-5.

45. Hammarlund E, Smith, M.P., Rasmussen, J., Nielsen, A., Canfield, D., Harper, D. The Sirius Passet Lagerstätte of North Greenland - a geochemical window on early Cambrian low oxygen environments and ecosystems. Geobiology. in review;

46. Powell WG, Johnston PA, Collom CJ. Geochemical evidence for oxygenated bottom waters during deposition of fossiliferous strata of the Burgess Shale Formation. Palaeogeogr Palaeoclimatol Palaeoecol. 2003 Dec 5;201(3):249-68.

47. Boudec AL, Ineson J, Rosing M, Døssing L, Martineau F, Lécuyer C, et al. Geochemistry of the Cambrian Sirius Passet Lagerstätte, Northern Greenland. Geochem Geophys Geosystems. 2014 Apr 1;15(4):886-904.

48. McKirdy DM, Hall PA, Nedin C, Halverson GP, Michaelsen BH, Jago JB, et al. Paleoredox status and thermal alteration of the lower Cambrian (Series 2) Emu Bay Shale Lagerstätte, South Australia. Aust J Earth Sci. 2011 Apr 1;58(3):259-72.

49. Kimmig J, Pratt BR. Taphonomy of the middle Cambrian (Drumian) Ravens Throat River Lagerstätte, Rockslide Formation, Mackenzie Mountains, Northwest Territories, Canada. Lethaia. 2016 Apr 1;49(2):150-69.

50. Novek JM, Dornbos SQ, McHenry LJ. Palaeoredox geochemistry and bioturbation levels of the exceptionally preserved early Cambrian Indian Springs biota, Nevada, USA. Lethaia. 2016 Oct 1;49(4):604-16.

51. Jones B, Manning DAC. Comparison of geochemical indices used for the interpretation of palaeoredox conditions in ancient mudstones. Chem Geol. 1994;111:111-29.

52. Pope MC, Hollingsworth JS, Dilliard K. Overview of Lower Cambrian mixed carbonatesiliciclastic deposition along the western Laurentian passive margin. In: Derby JR, Fritz RD, Longacre SA, Morgan WA, Sternbach CA, editors. The great American carbonate bank: The geology and economic resources of the Cambrian-Ordovician Suak megasequence of Laurentia. AAPG Memoir; 2012. p. 735-50.

53. Pyle LJ. Cambrian and Lower Ordovician Sauk megasequence of northwestern Canada, northern Rocky Mountains to the Beaufort Sea. In: Derby JR, Fritz RD, Longacre SA, Morgan WA, Stembach CA, editors. The great American carbonate bank: The geology and 
economic resources of the Cambrian-Ordovician Sauk megasequence of Laurentia. 2012. p. 675-723.

54. Slind OL, Perkins GD. Lower Paleozoic and Proterozoic sediments of the Rocky Mountains between Jasper, Alberta and Pine River, British Columbia. Bull Can Pet Geol. 1966;14(4):442-68.

55. McMechan ME. Upper Proterozoic to Middle Cambrian history of the Peace River Arch: evidence from the Rocky Mountains. Bull Can Pet Geol. 1990;38(1):36-44.

56. Bond GC, Christie-Blick N, Kominz MA, Devlin WJ. An early Cambrian rift to post-rift transition in the Cordillera of western North America. Nature. 1985;315:742-6.

57. Lickorish WH, Simony PS. Evidence for late rifting of the Cordilleran margin outlined by stratigraphic division of the Lower Cambrian Gog Group, Rocky Mountain Main Ranges, British Columbia and Alberta. Can J Earth Sci. 1995 Jul 1;32(7):860-74.

58. Fritz WH. Walcott's lower Cambrian olenellid trilobite collection 61K, Mount Robson area, Canadian Rocky Mountains /. Ottawa, Canada : Geological Survey of Canada,; 1992.

59. Fritz WH, Mountjoy EW. Lower and early Middle Cambrian formations near Mount Robson, British Columbia and Alberta. Can J Earth Sci. 1975;12(2):119-31.

60. Walcott CD. New Lower Cambrian subfauna. Smithson Misc Collect. 1913;57:309-26.

61. Balthasar U. Mummpikia Gen. Nov. and the origin of calcitic-shelled brachiopods. Palaeontology. 2008;51:263-79.

62. Balthasar U. Shell structure, ontogeny and affinities of the Lower Cambrian bivalved problematic fossil Mickwitzia muralensis. Lethaia. 2004;37:381-400.

63. Ortega-Hernández J, Esteve J, Butterfield NJ. Humble origins for a successful strategy: complete enrolment in early Cambrian olenellid trilobites. Biol Lett. 2013 Oct 23;9(5):20130679.

64. Balthasar U, Butterfield NJ. Early Cambrian "soft-shelled" brachiopods as possible stemgroup phoronids. Acta Palaeontol Pol. 2009;54:307-14.

65. Canfield DE, Raiswell R, Westrich JT, Reaves CM, Berner RA. The use of chromium reduction in the analysis of reduced inorganic sulfur in sediments and shale. Chem Geol. 1986;54:149-55.

66. Poulton SW, Canfield DE. Development of a sequential extraction procedure for iron: implications for iron partitioning in continentally derived particulates. Chem Geol. 2005;214:209-21.

67. Anbar AD, Duan Y, Lyons TW, Arnold GL, Kendall B, Creaser RA, et al. A whiff of oxygen before the Great Oxidation Event? Science. 2007;317:1903-6. 
68. Read PB, Woodsworth GJ, Greenwood HJ, Ghent ED, Evenchick CA. Metamorphic map of the Canadian Cordillera. "A” Series Map 1714A. Geological Survey of Canada; 1991.

69. Diamond CW, Planavsky NJ, Wang C, Lyons, TW. What the $\sim 1.4$ Ga Xiamaling Formation can and cannot tell us about the mid-Proterozoic ocean. Geobiology. 2018;16:219-36.

70. Slotznick SP, Eiler JM, Fischer WW. The effects of metamorphism on iron mineralogy and the iron speciation redox proxy. Geochim Cosmochim Acta. 2018 Mar 1;224:96-115.

71. Lyons TW, Severmann S. A critical look at iron paleoredox proxies: New insights from modern euxinic marine basins. Geochim Cosmochim Acta. 2006;70:5698-722.

72. Raiswell R, Newton R, Bottrell SH, Coburn PM, Briggs DEG, Bond DPG, et al. Turbidite depositional influences on the diagenesis of Beecher's Trilobite Bed and the Hunsrück Slate; sites of soft tissue pyritization. Am J Sci. 2008;308(2):105-29.

73. Paterson JR, García-Bellido DC, Lee MSY, Brock GA, Jago JB, Edgecombe GD. Acute vision in the giant Cambrian predator Anomalocaris and the origin of compound eyes. Nature. 2011 Dec;480(7376):237-40.

74. Ma X, Cong P, Hou X, Edgecombe GD, Strausfeld NJ. An exceptionally preserved arthropod cardiovascular system from the early Cambrian. Nat Commun. 2014 Apr 7;5:3560.

75. Ma X, Hou X, Edgecombe GD, Strausfeld NJ. Complex brain and optic lobes in an early Cambrian arthropod. Nature. 2012 Oct;490(7419):258-61.

76. Butterfield NJ. Leanchoilia guts and the interpretation of three-dimensional structures in Burgess Shale-type fossils. Paleobiology. 2002;28(1):155-71.

77. Boyer DL, Owens JD, Lyons TW, Droser ML. Joining Forces: Combined Biological and Geochemical Proxies Reveal A Complex but Refined High-Resolution Palaeo-oxygen History in Devonian Epeiric Seas. Palaeogeogr Palaeoclimatol Palaeoecol. 2011;306:134146.

78. Gaines RR, Droser ML. Paleoecology of the familiar trilobite Elrathia kingii: An early exaerobic zone inhabitant. Geology. 2003;31:941-4.

79. Garson DE, Gaines RR, Droser ML, Liddell WD, Sappenfield A. Dynamic palaeoredox and exceptional preservation in the Cambrian Spence Shale of Utah. Lethaia. 2011;

80. Ahm A-SC, Bjerrum CJ, Hammarlund EU. Disentangling the record of diagenesis, local redox conditions, and global seawater chemistry during the latest Ordovician glaciation. Earth Planet Sci Lett. 2017 Feb 1;459:145-56.

81. Scott C, Lyons TW. Contrasting molybdenum cycling and isotopic properties in euxinic versus non-euxinic sediments and sedimentary rocks: refining the paleoproxies. Chem Geol. 2012;324:19-27. 
82. Dahl TW, Ruhl M, Hammarlund EU, Canfield DE, Rosing MT, Bjerrum CJ. Tracing euxinia by molybdenum concentrations in sediments using handheld $\mathrm{X}$-ray fluorescence spectroscopy (HHXRF). Chem Geol. 2013;360:241-51.

83. Gaines RR, Hammarlund EU, Hou X, Qi C, Gabbott SE, Zhao Y, et al. Mechanism for Burgess Shale-type preservation. Proc Natl Acad Sci. 2012;109(14):5180-4.

84. Bergmann KD, Grotzinger JP, Fischer WW. Biological influences on seafloor carbonate precipitation. PALAIOS. 2013 Feb 1;28(2):99-115.

85. Anderson RP, Tosca NJ, Gaines RR, Koch NM, Briggs DEG. A mineralogical signature for Burgess Shale-type fossilization. Geology. 2018;

86. Petrovich R. Mechanisms of Fossilization of the Soft-Bodied and Lightly Armored Faunas of the Burgess Shale and of Some Other Classical Localities. Am J Sci. 2001 Oct 1;301(8):683726.

87. Wilson LA, Butterfield NJ. Sediment effects on the preservation of Burgess shale-type compression fossils. PALAIOS. 2014 Apr 1;29(4):145-54.

88. McMahon S, Anderson RP, Saupe EE, Briggs DEG. Experimental evidence that clay inhibits bacterial decomposers: Implications for preservation of organic fossils. Geology. 2016;44:867-70.

89. Canfield DE. Reactive iron in marine sediments. Geochim Cosmochim Acta. 1989;53(3):619-32.

90. Lyons TW, Reinhard CT, Planavsky NJ. The rise of oxygen in Earth's early ocean and atmosphere. Nature. 2014;506(7488):307-15.

91. Canfield DE, Farquhar J. Animal evolution, bioturbation, and the sulfate evolution of the oceans. Proc Natl Acad Sci USA. 2009;106:8123-7.

92. Lyons TW. A perfect (geochemical) storm yielded exceptional fossils in the early ocean. Proc Natl Acad Sci. 2012 Apr 3;109(14):5138-9.

93. Montjoy EW. Geology, Mount Robson, West of Sixth Meridian, Alberta-British Columbia. Geological Survey of Canada; 1980. (“A” Map Series Map 1499A). 

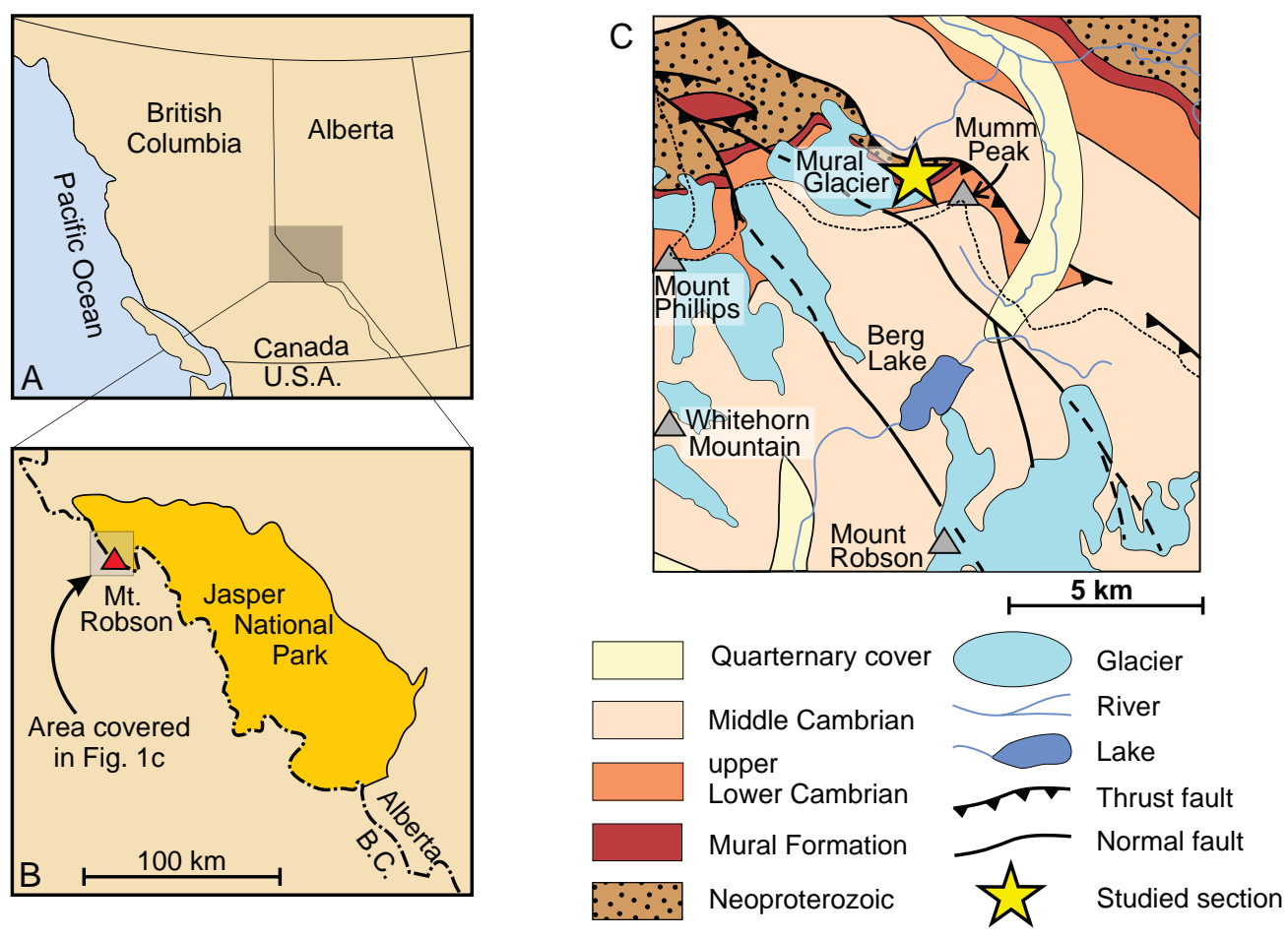


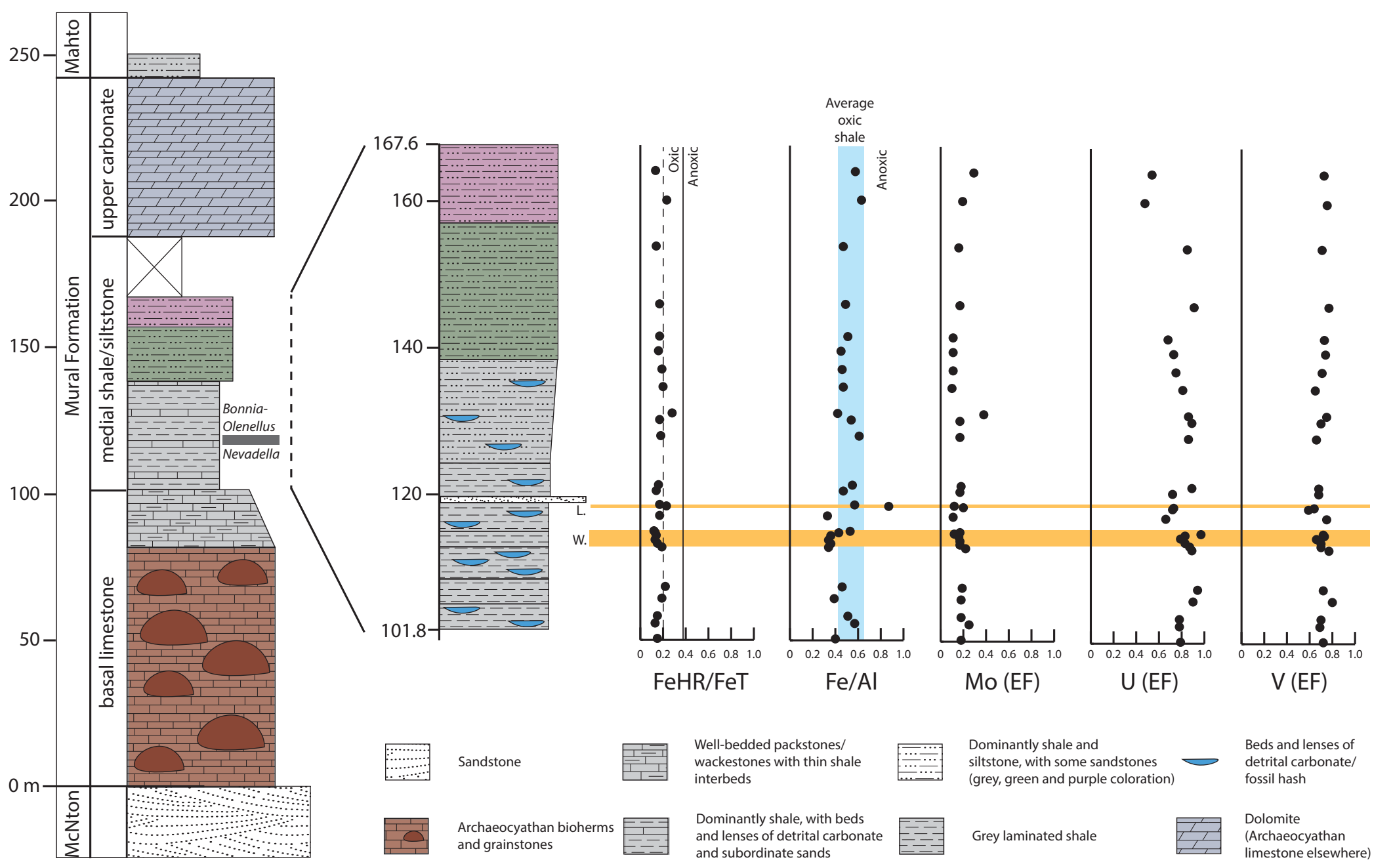


SGP sample_iOriginal_num Height_in_se Lithology 3321 S1409-100.2 3322 S1409-102.3 3323 S1409-103.3 3324 S1409-105.7 3325 S1409-107.3 3326 S1409-112.7 3327 S1409-113.2 3328 S1409-113.7 3329 S1409-114.3 3330 S1409-114.7 3331 S1409-114.9 3332 S1409-117 3333 S1409-118.3 3334 S1409-118.5 3335 S1409-120.4 3336 S1409-121.2 3337 S1409-127.9 3338 S1409-130.1 3339 S1409-131 3340 S1409-134.6 3341 S1409-137 3342 S1409-139.5 3343 S1409-141.5 3344 S1409-145.9 3345 S1409-153.8 3346 S1409-160.1 3347 S1409-164

\begin{abstract}
100.2 shale
\end{abstract}
102.3 shale

103.3 shale

105.7 shale

107.3 shale

112.7 shale

113.2 shale

113.7 shale

114.3 shale

114.7 shale

114.9 shale

117 shale

118.3 shale

118.5 shale

120.4 shale

121.2 shale

127.9 shale

130.1 shale

131 shale

134.6 shale

137 shale

139.5 shale

141.5 shale

145.9 shale

153.8 shale

160.1 shale

164 shale
Fe-carb (wt\% Fe-ox (wt\%) Fe-mag (wt\%

$\begin{array}{lll}0.188 & 0.176 & 0.122\end{array}$

$\begin{array}{lll}0.267 & 0.144 & 0.145\end{array}$

$\begin{array}{lll}0.177 & 0.218 & 0.186\end{array}$

$\begin{array}{lll}0.127 & 0.225 & 0.097\end{array}$

$\begin{array}{lll}0.148 & 0.421 & 0.165\end{array}$

$\begin{array}{lll}0.138 & 0.218 & 0.098\end{array}$

$\begin{array}{lll}0.112 & 0.108 & 0.123\end{array}$

$\begin{array}{lll}0.113 & 0.053 & 0.151\end{array}$

$\begin{array}{lll}0.108 & 0.097 & 0.173\end{array}$

$\begin{array}{lll}0.144 & 0.085 & 0.18\end{array}$

$\begin{array}{lll}0.161 & 0.073 & 0.179\end{array}$

$\begin{array}{lll}0.102 & 0.115 & 0.077\end{array}$

$\begin{array}{lll}0.241 & 0.476 & 0.375\end{array}$

$\begin{array}{lll}0.21 & 0.161 & 0.298\end{array}$

$\begin{array}{lll}0.166 & 0.042 & 0.187\end{array}$

$\begin{array}{lll}0.248 & 0.058 & 0.195\end{array}$

$\begin{array}{lll}0.499 & 0.078 & 0.27\end{array}$

$\begin{array}{lll}0.339 & 0.08 & 0.218\end{array}$

$\begin{array}{lll}0.214 & 0.174 & 0.15\end{array}$

$\begin{array}{lll}0.245 & 0.095 & 0.186\end{array}$

$\begin{array}{lll}0.183 & 0.041 & 0.156\end{array}$

$\begin{array}{lll}0.238 & 0.054 & 0.224\end{array}$

$\begin{array}{lll}0.313 & 0.06 & 0.277\end{array}$

$\begin{array}{lll}0.125 & 0.344 & 0.237\end{array}$

$0.14 \quad 0.097 \quad 0.16$

$\begin{array}{lll}0.143 & 0.964 & 0.218\end{array}$

$\begin{array}{lll}0.117 & 0.461 & 0.129\end{array}$

$\begin{array}{llll}\text { Average } & 0.19 & 0.19 & 0.18 \\ \text { Standard Dev } & 0.09 & 0.20 & 0.07\end{array}$




\begin{tabular}{|c|c|c|c|c|c|c|}
\hline Fe-py (wt\%) & FeT (wt\%) & FeHR & FeHR/FeT & Fe-py/FeHR & $\mathrm{FeT} / \mathrm{Al}$ & TOC (wt\%) \\
\hline 0.079 & 3.82 & 0.57 & 0.15 & 0.14 & 0.4 & 0.13 \\
\hline 0.089 & 4.87 & 0.65 & 0.13 & 0.14 & 0.57 & 0.13 \\
\hline 0.109 & 4.51 & 0.69 & 0.15 & 0.16 & 0.51 & 0.15 \\
\hline 0.232 & 3.5 & 0.68 & 0.19 & 0.34 & 0.39 & 0.12 \\
\hline 0.128 & 3.94 & 0.86 & 0.22 & 0.15 & 0.46 & 0.18 \\
\hline 0.189 & 3.32 & 0.64 & 0.19 & 0.3 & 0.34 & 0.19 \\
\hline 0.238 & 4.03 & 0.58 & 0.15 & 0.41 & 0.36 & 0.16 \\
\hline 0.185 & 3.95 & 0.51 & 0.13 & 0.37 & 0.34 & 0.16 \\
\hline 0.166 & 4.22 & 0.55 & 0.14 & 0.31 & 0.36 & 0.16 \\
\hline 0.182 & 4.54 & 0.59 & 0.13 & 0.31 & 0.43 & 0.19 \\
\hline 0.216 & 5.67 & 0.63 & 0.12 & 0.35 & 0.53 & 0.22 \\
\hline 0.272 & 3.24 & 0.56 & 0.17 & 0.48 & 0.33 & 0.18 \\
\hline 0.514 & 7.46 & 1.6 & 0.23 & 0.32 & 0.87 & 0.15 \\
\hline 0.284 & 5.83 & 0.95 & 0.17 & 0.3 & 0.57 & 0.13 \\
\hline 0.219 & 4.45 & 0.62 & 0.14 & 0.36 & 0.47 & 0.14 \\
\hline 0.276 & 4.97 & 0.78 & 0.16 & 0.36 & 0.55 & 0.15 \\
\hline 0.185 & 5.66 & 1.04 & 0.18 & 0.18 & 0.61 & 0.13 \\
\hline 0.2 & 5.02 & 0.84 & 0.17 & 0.24 & 0.54 & 0.15 \\
\hline 0.648 & 4.22 & 1.19 & 0.28 & 0.55 & 0.42 & 0.14 \\
\hline 0.47 & 4.87 & 1 & 0.2 & 0.47 & 0.47 & 0.11 \\
\hline 0.465 & 4.58 & 0.85 & 0.19 & 0.55 & 0.46 & 0.15 \\
\hline 0.211 & 4.43 & 0.73 & 0.16 & 0.29 & 0.45 & 0.12 \\
\hline 0.196 & 4.92 & 0.85 & 0.17 & 0.24 & 0.51 & 0.09 \\
\hline 0.057 & 4.63 & 0.77 & 0.17 & 0.08 & 0.49 & 0.12 \\
\hline 0.234 & 4.59 & 0.63 & 0.14 & 0.37 & 0.47 & 0.1 \\
\hline 0.006 & 5.91 & 1.34 & 0.23 & 0.01 & 0.62 & 0.12 \\
\hline 0.012 & 5.43 & 0.72 & 0.13 & 0.01 & 0.57 & 0.1 \\
\hline 0.22 & 4.69 & 0.79 & 0.17 & 0.29 & 0.48 & 0.14 \\
\hline 0.15 & 0.91 & 0.26 & 0.04 & 0.15 & 0.11 & 0.03 \\
\hline
\end{tabular}




\begin{tabular}{|c|c|c|c|c|c|c|c|}
\hline $\mathrm{Al}(\mathrm{wt} \%)$ & $\mathrm{Ca}$ (wt\%) & $\mathrm{K}(w t \%)$ & $\mathrm{Mg}(w t \%)$ & $\mathrm{Mn}(\mathrm{ppm})$ & Mo (ppm) & Mo EF & \\
\hline 9.08 & 1.27 & 4.37 & 1.36 & 245 & 0.3 & & 0.18 \\
\hline 8.48 & 4.11 & 3.8 & 1.38 & 629 & 0.4 & & 0.25 \\
\hline 8.85 & 0.77 & 4.18 & 1.36 & 246 & 0.3 & & 0.18 \\
\hline 8.96 & 0.09 & 4.92 & 0.97 & 82 & 0.3 & & 0.18 \\
\hline 8.52 & 0.11 & 4.16 & 1.05 & 105 & 0.3 & & 0.19 \\
\hline 9.64 & 0.09 & 5.42 & 0.81 & 104 & 0.4 & & 0.22 \\
\hline 9.21 & 0.07 & 4.91 & 1 & 167 & 0.3 & & 0.17 \\
\hline 9.71 & 0.14 & 4.67 & 1.05 & 195 & 0.3 & & 0.17 \\
\hline 9.84 & 0.26 & 4.66 & 1.12 & 255 & 0.3 & & 0.16 \\
\hline 9 & 0.34 & 5.13 & 1.12 & 265 & 0.2 & & 0.12 \\
\hline 9.2 & 0.09 & 4.59 & 1.21 & 241 & 0.3 & & 0.17 \\
\hline 9.96 & 0.07 & 5.68 & 0.82 & 106 & 0.2 & & 0.11 \\
\hline 8 & 0.47 & 2.57 & 1.86 & 703 & 0.3 & & 0.2 \\
\hline 8.99 & 0.44 & 3.42 & 1.48 & 479 & 0.2 & & 0.12 \\
\hline 9.51 & 0.27 & 4.39 & 1.09 & 276 & 0.3 & & 0.17 \\
\hline 9.03 & 0.4 & 4.1 & 1.2 & 539 & 0.3 & & 0.18 \\
\hline 9.33 & 0.72 & 3.92 & 1.45 & 1120 & 0.3 & & 0.17 \\
\hline 9.38 & 0.41 & 4.45 & 1.25 & 911 & 0.3 & & 0.17 \\
\hline 9.97 & 0.3 & 5.2 & 0.86 & 737 & 0.7 & & 0.38 \\
\hline 10.3 & 0.3 & 5.07 & 1.11 & 726 & 0.2 & & 0.1 \\
\hline 9.9 & 0.08 & 4.82 & 1.19 & 556 & 0.2 & & 0.11 \\
\hline 9.89 & 0.06 & 4.73 & 1.14 & 888 & 0.2 & & 0.11 \\
\hline 9.74 & 0.15 & 4.44 & 1.18 & 1256 & 0.2 & & 0.11 \\
\hline 9.42 & 0.08 & 3.94 & 0.98 & 588 & 0.3 & & 0.17 \\
\hline 9.83 & 0.04 & 4.23 & 1.02 & 266 & 0.3 & & 0.16 \\
\hline 9.55 & 0.08 & 2.62 & 1.16 & 1295 & 0.2 & & 0.17 \\
\hline 9.57 & 0.1 & 2.78 & 1.11 & 399 & 0.3 & & 0.17 \\
\hline 9.37 & 0.42 & 4.34 & 1.16 & 495.52 & 0.29 & & 0.17 \\
\hline 0.53 & 0.79 & 0.79 & 0.22 & 359.41 & 0.10 & & 0.06 \\
\hline
\end{tabular}




\begin{tabular}{|c|c|c|c|c|c|c|}
\hline $\mathrm{Na}$ (wt\%) & $P(p p m)$ & Th (ppm) & $\mathrm{Ti}(w t \%)$ & $U(p p m)$ & UEF & $V(p p m)$ \\
\hline 0.933 & 470 & 18.6 & 0.426 & 2.5 & 0.79 & 87 \\
\hline 0.944 & 480 & 16.4 & 0.374 & 2.3 & 0.78 & 78 \\
\hline 0.945 & 540 & 17.7 & 0.371 & 2.4 & 0.78 & 83 \\
\hline 0.805 & 370 & 17.3 & 0.441 & 2.8 & 0.9 & 95 \\
\hline 0.783 & 520 & 19 & 0.391 & 2.8 & 0.94 & 82 \\
\hline 0.547 & 540 & 15.7 & 0.444 & 3 & 0.89 & 99 \\
\hline 0.639 & 350 & 16.3 & 0.431 & 2.8 & 0.87 & 86 \\
\hline 0.535 & 540 & 15.4 & 0.428 & 2.8 & 0.83 & 90 \\
\hline 0.532 & 880 & 17.4 & 0.407 & 2.7 & 0.79 & 87 \\
\hline 0.523 & 990 & 15.3 & 0.397 & 2.6 & 0.83 & 88 \\
\hline 0.601 & 340 & 16.8 & 0.398 & 3.1 & 0.97 & 88 \\
\hline 0.565 & 280 & 16.2 & 0.455 & 2.3 & 0.66 & 100 \\
\hline 0.987 & 1430 & 15 & 0.309 & 2 & 0.72 & 63 \\
\hline 0.89 & 1150 & 20.3 & 0.429 & 2.3 & 0.73 & 76 \\
\hline 0.818 & 550 & 16.7 & 0.433 & 2.4 & 0.72 & 86 \\
\hline 0.73 & 730 & 19.3 & 0.444 & 2.8 & 0.89 & 82 \\
\hline 0.649 & 870 & 17.8 & 0.432 & 2.8 & 0.86 & 82 \\
\hline 0.556 & 600 & 17.2 & 0.431 & 2.9 & 0.89 & 87 \\
\hline 0.465 & 590 & 19.8 & 0.469 & 3 & 0.86 & 99 \\
\hline 0.403 & 650 & 17.9 & 0.419 & 2.9 & 0.81 & 89 \\
\hline 0.407 & 230 & 15.1 & 0.382 & 2.6 & 0.75 & 93 \\
\hline 0.472 & 270 & 16.3 & 0.426 & 2.5 & 0.73 & 98 \\
\hline 0.81 & 640 & 14.2 & 0.364 & 2.3 & 0.68 & 94 \\
\hline 0.284 & 330 & 18.6 & 0.46 & 3 & 0.91 & 96 \\
\hline 0.337 & 230 & 15 & 0.385 & 2.9 & 0.85 & 93 \\
\hline 0.266 & 300 & 12.4 & 0.362 & 1.6 & 0.48 & 94 \\
\hline 0.277 & 260 & 13.1 & 0.376 & 1.8 & 0.54 & 92 \\
\hline 0.62 & 560.37 & 16.70 & 0.41 & 2.59 & 0.79 & 88.41 \\
\hline 0.22 & 295.55 & 1.94 & 0.04 & 0.38 & 0.11 & 8.21 \\
\hline
\end{tabular}




\begin{tabular}{|c|c|c|}
\hline VEF & $\mathrm{Zn}(\mathrm{ppm})$ & $\mathrm{Zr}(\mathrm{ppm})$ \\
\hline 0.72 & 51 & 74.7 \\
\hline 0.69 & 60 & 70.1 \\
\hline 0.7 & 62 & 68.1 \\
\hline 0.8 & 54 & 73 \\
\hline 0.72 & 56 & 81.5 \\
\hline 0.77 & 41 & 80.2 \\
\hline 0.7 & 58 & 68.6 \\
\hline 0.7 & 66 & 68.8 \\
\hline 0.66 & 71 & 61.1 \\
\hline 0.73 & 70 & 59.9 \\
\hline 0.72 & 103 & 59.7 \\
\hline 0.75 & 37 & 69.8 \\
\hline 0.59 & 124 & 45.5 \\
\hline 0.64 & 92 & 60.3 \\
\hline 0.68 & 61 & 59.9 \\
\hline 0.68 & 80 & 63.4 \\
\hline 0.66 & 109 & 55.9 \\
\hline 0.7 & 100 & 57 \\
\hline 0.75 & 61 & 70.4 \\
\hline 0.65 & 83 & 61.8 \\
\hline 0.71 & 93 & 64.1 \\
\hline 0.74 & 88 & 72.2 \\
\hline 0.73 & 96 & 67.9 \\
\hline 0.77 & 73 & 78.5 \\
\hline 0.71 & 76 & 75.2 \\
\hline 0.74 & 78 & 36.3 \\
\hline 0.72 & 68 & 38.5 \\
\hline 0.71 & 74.48 & 64.53 \\
\hline 0.04 & 21.04 & 11.27 \\
\hline
\end{tabular}

